Low-Cost Solar Array Project

5101-65
DOE/JPL-1012-78/7A

Distribution Category UC-63b

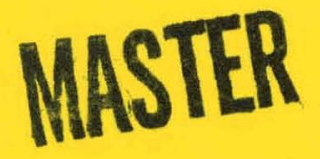

\title{
Photovoltaic Module Design, Qualification and Testing Specification
}

March 24, 1978 


\section{DISCLAIMER}

This report was prepared as an account of work sponsored by an agency of the United States Government. Neither the United States Government nor any agency Thereof, nor any of their employees, makes any warranty, express or implied, or assumes any legal liability or responsibility for the accuracy, completeness, or usefulness of any information, apparatus, product, or process disclosed, or represents that its use would not infringe privately owned rights. Reference herein to any specific commercial product, process, or service by trade name, trademark, manufacturer, or otherwise does not necessarily constitute or imply its endorsement, recommendation, or favoring by the United States Government or any agency thereof. The views and opinions of authors expressed herein do not necessarily state or reflect those of the United States Government or any agency thereof. 


\section{DISCLAIMER}

Portions of this document may be illegible in electronic image products. Images are produced from the best available original document. 
Prepared by the Jet Propulsion Laboratory, California Institute of Technology, for the Department of Energy by agreement with the National Aeronautics and Space Administration.

The JPL Low-cost Solar Array Project is sponsored by the Department of Energy (DOE) and forms part of the Solar Photovoltaic Conversion Program to initiate a major effort toward the development of low-cost solar arrays.

This report was prepared as an account of work sponsored by the United States Government. Neither the United States nor the United States Department of Energy, nor any of their employees, nor any of their contractors, subcontractors, or their employees, makes any warranty, express or implied, or assumes any legal liability or responsibility for the accuracy, completeness or usefulness of any information, apparatus, product or process disclosed, or represents that its use would not infringe privately owned rights. 


\section{Low-Cost Solar Array Project}

5101-65

\section{Photovoltaic Module Design, Qualification and Testing Specification}

LSA Engineering Area

March 24, 1978

Prepared for

Department of Energy

by

Jet Propulsion Laboratory

California Institute of Technology

Pasadena, California

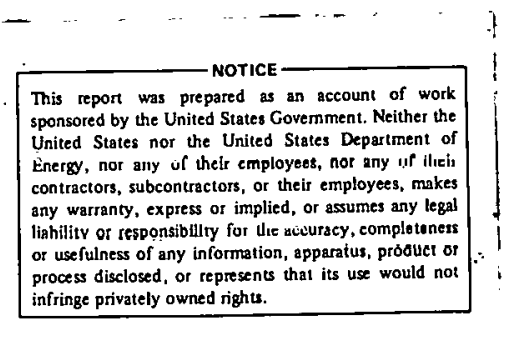


This specification was prepared by the Engineering Area of the Low-Cost Solar Array Project. Inquiries related to details of the document or requests for additional information should be directed to Dr. R. G. Ross, Jr., Engineering Area Manager or Mr. J. C. Arnett, Cognizant Module Design Engineer. 
I. INTRODUCTION -- 1-1

A. SCOPE ---

B. APPLICABLE DOCUMENTS - 1-1

II. DESIGN CRITERIA - 2-1

A. PERFORMANCE MEASUREMENT CRITERIA -------------- 2-1

B. ELECTRICAL DESIGN REQUIREMENTS -

C. MECHANICAL DESIGN REQUIREMENTS -- 2-3

D. ENVIRONMENTAL DESIGN REQUIREMENTS -- 2-5.

III. QUALIFICATION AND ACCEPTANCE REQUIREMENTS ------------- 3-I

A. PERFORMANCE CHARACTERIZATION REQUIREMENTS -------- 3-1

B. DESIGN QUALIFICATION TEST REQUIREMENTS---------- 3-3

C. MODULE ACCEPTANCE REQUIREMENTS - $3-4$

IV. PERFORMANCE MEASUREMENT PROCEDURES -- 4-1

A. ELECTRICAL PERFORMANCE -- 4-1

B. NOMINAL OPERATING CELL TEMPERATURE -- 4-2

1. Purpose - 4-2

2. Determination of NOCT - 4-2

3. Air Temperature and Wind Correction - 4-3

4. Test Geometry - 4-4

5. Test Equipment - 4-6

6. Data Recording - 4

7. Cleaning - 4-7

8. Equipment Calibration - 4-7 
V.

A. THERMAL CYCLING TEST. PROCEDURE-- 5-1

B. HUMIDITY TEST PROCEDURE:- 5-1

C. MECHANICAL CYCLING TEST PROCEDURE-

D. TWISTED MOUNTING SURFACE TEST PROCEDURE--

E. HAIL IMPACT TEST PROCEDURE- 5-1

F. ELECTRICAL ISOLATION TEST PROCEDURE--

\section{Figures}

2-1. Suggested Module Standard Dimensions--

3-1. Characterization and Qualification Test Flow Plan----- 3-2

4-1. Typical Cell Temperature Data

4-2. NOCT Correction Factor- 4-5

5-1. Thermal Cycle Test-- 5-4

$J=2$. Hunldlty Cycle Test--

5-3. Graphical Representation of "Twisted Mnunting Surface" Requi rement--_- 5-5

Table

5-1. Typica1. Hail Characteristice-- 


\section{SECTION I}

\section{INTRODUCTION}

\section{A. $\quad \mathrm{SCOPE}$}

This specification establishes minimum design, qualification and acceptance requirements for terrestrial solar cell modules suitable for incorporation in photovoltaic array applications in the $20 \mathrm{~kW}$ to $500 \mathrm{~kW}$ range, such as defined by Department of Energy PRDA EM-D-04-0038. Both mandatory and recommended requirement levels for selected performance criteria have been specified for modules within these arrays. As applicable, the manufacturer/contractor shall be responsible for generation and selection of appropriate design or test levels within the scope of these criteria. Specification of any additional requirements as necessary to satisfy the particular array or system application shall be the responsibility of the manufacturer/contractor. Environmental requirements imposed by this specification are considered to be the minimum level acceptable to DOE.

\section{B. APPLICABLE DOCUMENTS}

The following documentation is applicable to the extent specified:

(1) Military: MIL-STD-810 C, Environmental Test Methods, March 10, 1975.

(2) Energy Research and Development Administration: ERDA/NASA/1022-77/16 "Terrestrial Photovoltaic Measurement "Procedures" June 1977, Lewis Research Center, Cleveland, Ohio, 44135.

(3) Jet Propulsion Laboratory: LSSA Project Document 5101-21, Revision A, "Rejection Criteria for LSSA Modules", dated August 22, 1977. 
Solar cell modules meeting the requirements of this document will be mounted or grouped into an array structure compatible with system design constraints for photovoltaic applications ranging from $20 \mathrm{~kW}$ to $500 \mathrm{~kW}$ : The module designs shall satisfy the following general design criteria.

\section{A. PERFORMANCE MEASUREMENT CRITERIA}

The following standard performance measurement criteria shall be utilized:

(1) Power Output - The power output of individual modules shall be determined per Paragraph IV.A as the product of the module Nominal Operating Voltage $\left(\mathrm{V}_{\mathrm{NO}}\right)$ and the module current measured at $\mathrm{V}_{\mathrm{NO}}$ under Standard Operating Conditions (SOC), defined as an irradiance level of $100 \mathrm{~mW} / \mathrm{cm}^{2}$ and cell temperature equal to the Nominal Operating Cell Temperature (NOCT).

(2) Nominal Operating Voltage - The nominal operating voltage $\left(\mathrm{V}_{\mathrm{NO}}\right)$ is:the reference voltage level at which the modules are designed to provide maximum power output at standard operating conditions ( $100 \mathrm{~mW} / \mathrm{cm}^{2}$, NOCT). The $V_{\text {NO }}$ level shall be selected by the module manufacturer/system designer as a convenient fraction of the system working voltage. For purposes of standardization, a convenient fraction or multiple of 15 volts is suggested.

(3) Nominal Operating Cell Temperature - The Nominal Operating Cell Temperature is the module cell temperature under operating conditions in the Nominal Thermal Environment (N'l'E) which is defined as:

$$
\begin{aligned}
& \text { Tnsolation }=80 \mathrm{~mW} / \mathrm{cm}^{2} \\
& \text { Air Temperature }=20^{\circ} \mathrm{C} \\
& \text { Wind Average Velocity }=1 \mathrm{~m} / \mathrm{s} \\
& \text { Mounting }=\mathrm{Tillted} ; \text { Open Back, Open Circuit }
\end{aligned}
$$

The NOCT measurement procedure is described in Paragraph IV.B. 


\section{B. ELECTRICAL DESIGN REQUIREMENTS}

The electrical design of the module shall meet the following requirements :

(1) Electrical Voltage Isolation - All module circuitry, including output terminations, shall be insulated from external surfaces. The manufacturer/contractor shall establish the voltage isolation requirement on the basis of the maximum open circuit voltage of the complete system at an ambient temperature of $-20^{\circ} \mathrm{C}$, with $100 \mathrm{~mW} / \mathrm{cm}^{2}$ irradiance. The design level shall be set at twice this system voltage plus $1000 \mathrm{~V}_{\mathrm{DC}}$.

(2) Electrical Grounding and Safety - In order to minimize electrical hazard to personnel, all modules shall be provided with an external grounding terminal or stud serving ae a common grounding point for all exposed external. conductive surfaces not part of the module circuitry. A grounding stud is not required for modules designed for systems with operating voltage levels less than 50 volts or for modules without exposed conductive surfaces, unless removal of covers or mounting hardware will expose such surfaces.

(3) Cell String Circuit Réliability/Redundancy - Circuit redundancy features shall be incorporated where cost effective to enhance the reliability and manufacturing yield of completed modules. Design features may include, but are not limited to the following:

(a) Redundant intercomectiono between golar cells, including redundant cell attachment points.

(b) Series/parallel interconncction of cells within the module.

(c) Integral by-pass diodes within each module.

The decision to incorporate redundancy features shall be based on the expected percent improvement in lifetime/yield and replacement cost as contrasted with the percent increase in module cost/watt. Series/parallel circuit arrangcmcnta, when used, shall be designed so that "hot-spot" cell heating does not lead to further module degradation under worstcase-single-cel1-failure conditions defined as follows:

(a) The module output is short circuited.

(b) A single representative solar cell is open circuited to represent a single cell failure.

(c) The incident irradiance is $100 \mathrm{~mW} / \mathrm{cm}^{2}, \mathrm{AML} .5$.

(d) The thermal boundary conditions are adjusted so that the equilibrium solar cell temperature outside of the hot-spot region is equal to $\mathrm{NOCT}+20^{\circ} \mathrm{C}$. 


\section{MECHANICAL DESIGN REQUIREMENTS}

The mechanical design of the module shall meet the following requirements:

(1) Module Geometry - To meet the array/system requirements for mounting, each module shall meet the envelope, mechanical and interface requirements specified by an Interface Control Drawing to be prepared by the manufacturer/contractor, providing as a minimum the following information:

(a) Maximum envelope dimensions and tolerances;

(b) Location of output terminations;

(c) Mounting hole or attachment provisions, dimensions and tolerance;

(d) Illuminated (active) surface dimensions and shadowing or view angle constraints for low-level concentrators;

(e) Nominal electrical performance;

To allow for convenient handling and testing of modules from various suppliers, the maximum module dimensions shall not exceed 48 inches by 96 inches. Suggested standard dimensions and hole locations are provided in Figure $2-1$. In this figure the module width may be any dimension up to the 96-inch maximum.

(2) Interchangeability - All modules from a given manufacturer shall be physically and functionally interchangeable. Tolerances on all external module dimensions shall be maintained at a level consistent with module interchangeability. Surfaces, mounting holes and any attachment hardware associated with the attachment interfaces shall be maintained within tolerance specified in the Interface Control Drawing.

(3) Optical Surface Soiling - The illuminated optical surface(s) of the module shall be smooth, and generally free of projections which could promote entrapment of dust and other debris. Particular attention shall be given to selection of materials for the optical surface(s) which will minimize the accumulation of nonremovable contaminants, particulate matter and stains, and will promote self-cleaning by natural processes such as wind and rain. 


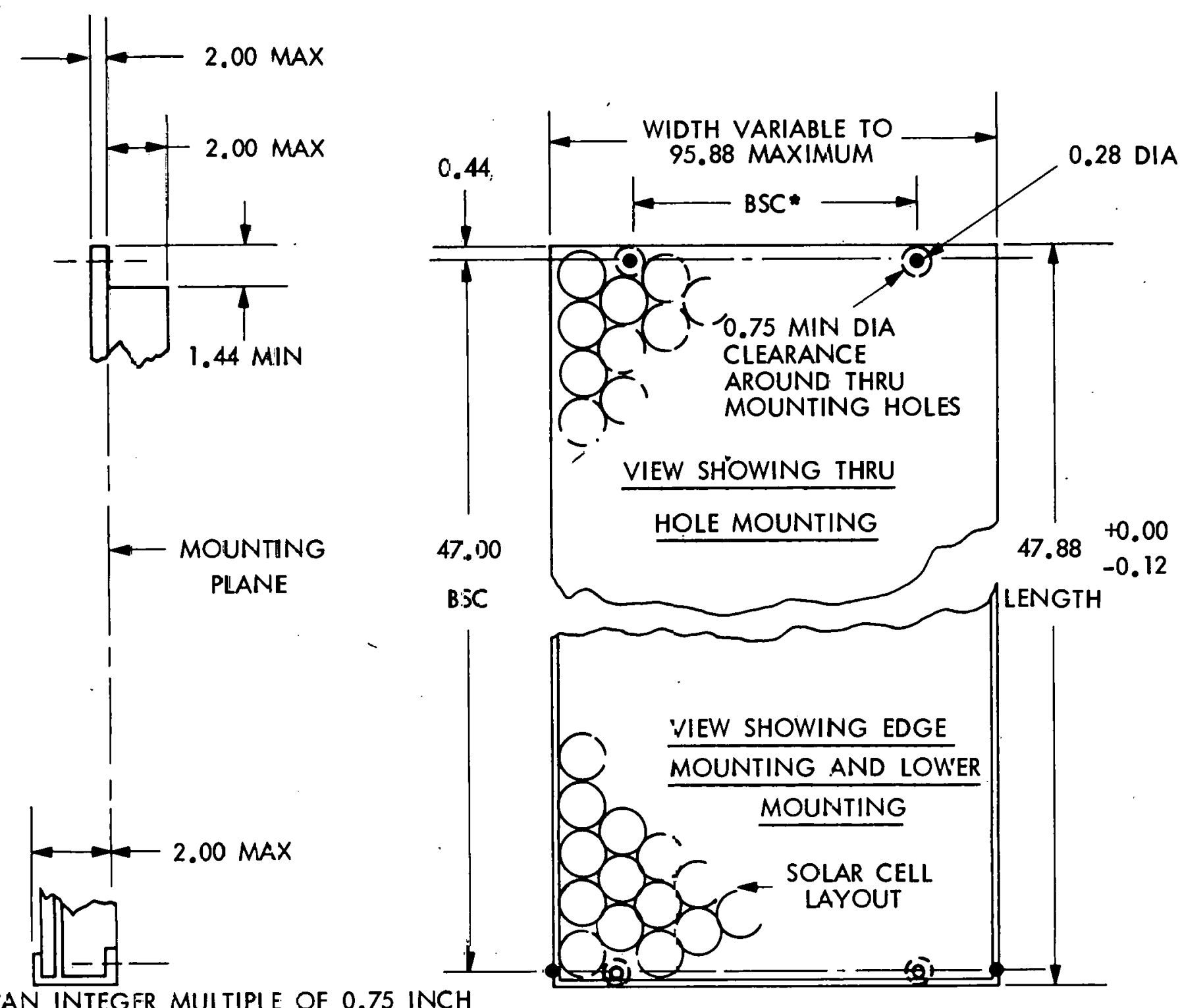

Figure 2-1. Siggested Module Standard Dimensions (a1l dimensions in inches) 
(4) Module Labeling and Identification - Each module shall be identified in a permanent and legible manner with suitable labels or markings specifying the manufacturer's module model number-(or drawing) and revision, sequential serial number, year and week of manufacture, and maximum system operating voltage for which the module is designed. Additional information may include the Nominal Operating Voltage and power of the module. The identification shall be installed at a position which is visible from the front (illuminated) side of each module, when installed in the array. The polarity of each electrical termination shall be marked in a permanent and legible manner in a position which is visible when accessing the electrical terminations in a completed array.

\section{ENVIRONMENTAL DESIGN REQUIREMENTS}

Environments to be considered in assessing possible degradation of module electrical performance and physical properties include: solar exposure (particularly UV); thermal conditions, including freezing and thawing; effects of wind, rain, snow, ice, hail, salt mist, and atmospheric oxidants; dust and debris accumulation, especially nonremovable stains or contamination; and, dynamic loading effects of wind, snow, and hail. As a minimum the module design shall be capable of withstanding exposure to the following environmental test environments:

(1) Thermal cycling from $-40^{\circ} \mathrm{C}$ to $+90^{\circ} \mathrm{C}$ per Test Procedure V.A.

(2) Humidity per Test Procedure V.B.

(3) Mechanical cyclic loading per procedure V.C. The test load level shall be determined by the manufacturer/contractor on the basis of the anticipated application site maximum wind gust velocity. A test level of \pm 50 pounds per square foot is common practice.

(4) Twisted mounting surface of $1 / 4$ inch per foot per Test Procedure V.D.

(5) Hail impact testing per Test Procedure V.E. The maximum size hailstones which the module shall withstand shall be determined by the manufacturer/contractor on the basis of an assessment of the hail risk at the intended application site.

The manufacturer/contractor shall establish additional environmental. requirements dictated by special environmental conditions at the intended application site. 


\section{QUALIFICATION AND ACCEPTANCE REQUIREMENTS}

\section{A. PERFORMANCE CHARACTERIZATION REQUIREMENTS}

The tests included in this section will be performed to characterize. the module performance and to provide a high level of confidence that production modules will function within the specified performance requirements. The characterization testing will be performed in the sequence shown in the flow diagram in Figure 3-1.

(1) Determination of Nominal Operating Cell Temperature

For purposes of providing a measurement of module performance that is representative of the anticipated terrestrial application, all module performance measurements are referenced to the Nominal Operating Cell Temperature (NOCT). NOCT is defined as the average cell temperature in the module under operating conditions in the Nominal Thermal Environment (NTE). The Nominal Thermal Environment is characterized by $80 \mathrm{~mW} / \mathrm{cm}^{2}$ insolation, ambient air temperature of $20^{\circ} \mathrm{C}$, average wind velocity of $1.0 \mathrm{~m} / \mathrm{s}$, with the module mounted in an open back condition (i.e., not insulated on back side), and electrical output terminations open-cịcuited. Actual cell temperatures shall be taken at conditions approximating NTE in order to obtain the solar cell NOCT. The NOCT shall be used for all measurements of module performance at Standard Operating Conditions ( $\mathrm{SOC}$ ). The approved techniques for performing the NOCT characterization test are included in Section IV.B.

\section{(2) Initial Electrical Measurement}

A minimum of five (5) prototype modules will be used to determine baseline electrical performance.

Measurements will be conducted at the NOCT determined per paragraph III.A.I and at the nominal operating voltage $\left(\mathrm{V}_{\mathrm{NO}}\right)$ specified by the manufacturer/contractor for the intended application. In addition to obtaining a baseline I-V characteristic curve for each module, the average output power $\left(\mathrm{P}_{a v g}\right)$ at nominal operating voltage shall be calculated from measurements of all prototype samples. Any sample producing less than $90 \%$ of this average power shall be replaced by an acceptable module prior to subjecting these modules to the design qualification tests (III.B). The output power determined for each module shall be the calculation base for determining extent of performance degradation during environmental qualification testing. 


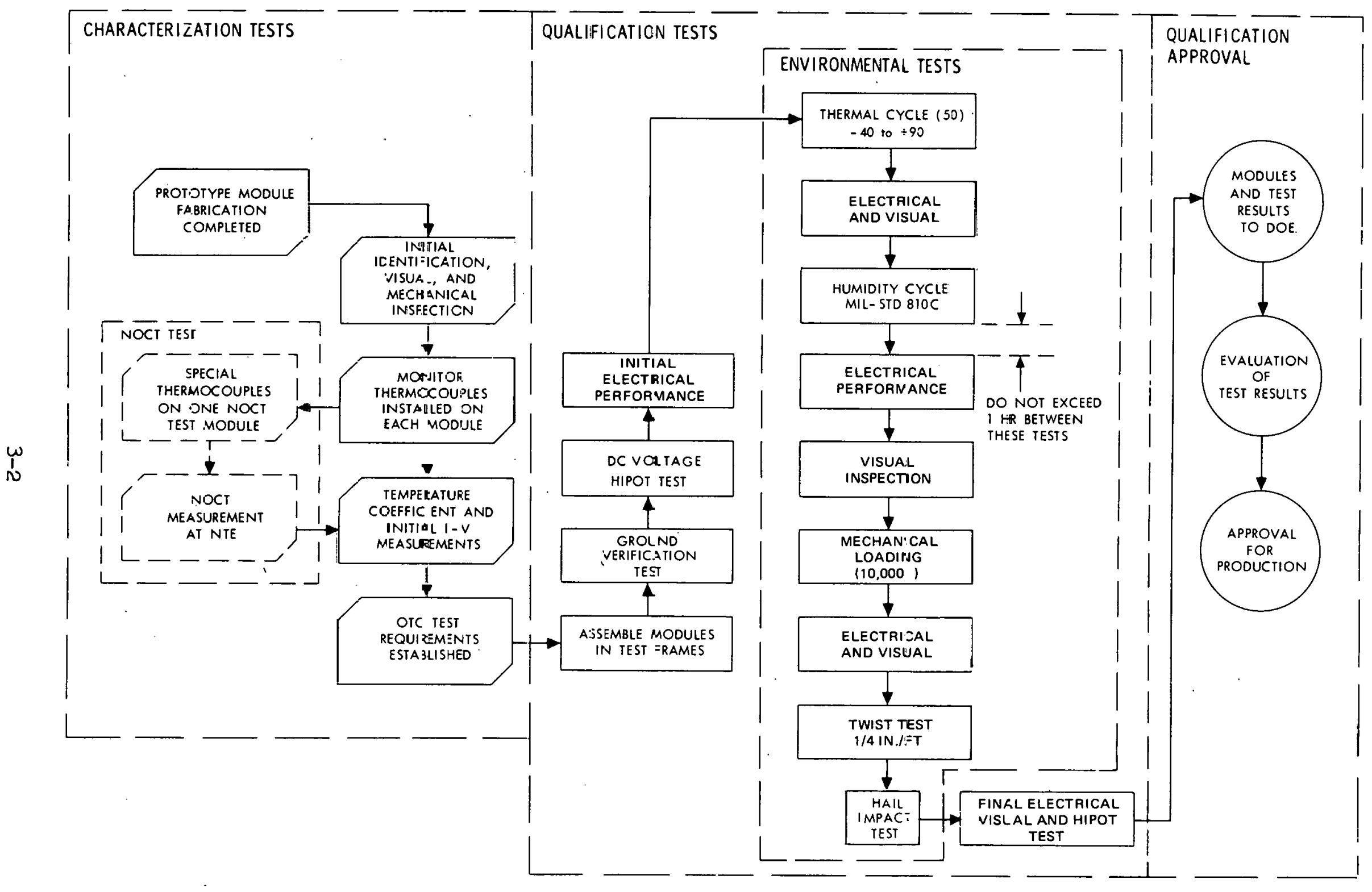

Figure 3-1. Characterization and Qualification Test Flow Plan 


\section{B. DESIGN QUALIFICATION TEST REQUIREMENTS}

This section specifies the minimum tests that shall be performed by the contractor/manufacturer in order to verify that the modules will satisfy the design requirements of this specification. DOE may, at its option, in addition to the characterization tests described in III.A, perform any or all of these tests on submitted prototype modules prior to approval of the module design for production. Modules shall, be mounted on rigid structural frame simulating the selected mounting interface and configuration for all design qualification testing. As a minimum, the following qualification tests shall be performed in the order listed. For clarification, the test sequence is shown in the flow, chart (Figure 3-1).

\section{(1) Ground Continuity Test}

Each module having exposed external conductive surfaces (i.e. frame or structural members) shall be tested using a suitable continuity tester to verify that electrical continuity exists between all such surfaces and the module grounding point. The maximum resistance to ground shall be 50 milliohms.

(2) Electrical Isolation Test

Each module shall be subjected to a DC voltage withstanding (Hi-Pot) test to assure the capability of the encapsulation system to provide adequate electrical isolation of internal circuitry. The test level shall equal the design level established by the manufacturer per paragraph II.B.1. Leakage current during the test shall not exceed 50 micro amps and there shall be no evidence of arcs, or flashover indicating insulation failure. Modules for which the maximum system voltage does not exceed $50 \mathrm{~V}_{\mathrm{DC}}$ are exempt from this requirement.

\section{(3) Environmental Testing}

Each module shall be subjected to the following environmental exposures, plus any additional special environmental tésts which the manufacturer/contractor may require for the intended application. These tests shall be conducted in the order indicated:

(a) Ground Continuity Test.

(b) Electrical Isolation Tests per Procedure V. F.

(c) Thermal Cycling Test per Procedure V.A.

(d) Humidity Cycling Test per Procedure V.B.

(e) Mechanical Cycling Test per Procedure V.C.

(f) Twisted Mounting Surface Test per Procedure V.D. 
(g) Hail Impact Test per Procedure V.E.

(h) Electrica1 Isolation Tests per Procedure V.F.

(i) Final Electrical Performance Test per Section IV.A.

Qualification Pass/Fail Criteria

The output power degradation of each tested module determined after completion of all qualification tests, shall not exceed $5 \%$ of the initial electrical performance determined per section III.A.2. The module shall pass the electrical isolation test (Procedure V.F.) when retested at completion of qualification tests. The allowable level ot observable cracks or other mechanical degradation (such as delamination of coatings) shall be determined by the manufacturer/contractor. Acceptable performance under the qualification testing requirements is a prerequisite for DOE approval of the module design.

\section{MODULE ACCEPTANCE REQUIREMENTS}

The contractor shall prepare a "Production Module Acceptance Testing Plan". This document is subject to review and approval by the UUE contract monitoring organization. This document shall indicate how the manufacturer/ contractor intends to screen production modules for verifying production workmanship and for charasterizing heginning of lifc conditions. The testing plan shall inrlude; but not be limited to sampling approach and rationale, and the following minimum tcot requirements: electrical performance, electrical isolation, and mechaniral and visual inspection.

\section{(1) Electrical Performance}

Each module shall be measured to determine its currentvoltagc characteristics ( $I-V$ curve). Measuremlents shall be made in accordance with paragraph IV.A. No module shall be accepted for delivery. which produces less than $90 \%$ of the Nominal Average Power under Standard Operating Conditions. The Nominal Average Power is defined as the average power at SOC and Nominal Operating Voltage $\left(V_{N O}\right)$ of 25 randomly selected modules of the first 200 modules produced.

(2) Electrical Isolation

Each module shall be subjected to a DC Hi-Pot test to assure adequate electrical isolation for safety of operating personnel at system operating voltages. 
(3) Mechanical and Visual Inspection

Modules shall be mechanically and visually inspected, on the basis of criteria to be established by the manufacturer, for acceptable/rejectable defects in workmanship and quality. One source of such criteria is JPL LSSA Document 5101-21, Revision A, dated August 22, 1977, entitled "Rejection Criteria for JPL LSSA Modules". 


\section{A. ELECTRICAL PERFORMANCE}

Electrical performance measurements shall be referenced to Standard Operating Conditions (SOC) defined as $100 \mathrm{~mW} / \mathrm{cm}^{2} \mathrm{AMl} .5$ irradiance, Nominal Operating Cell Temperature. All procedures, equipment and standards related to measurements shall conform to the latest revision of date of the contract of NASA TM 73702, Terrestrial Photovoltaic Measurement Procedures, dated June 1977. Manufacturer's conformance to this procedure is subject to acceptance by DOE. The reference cell, which shall be supplied by DOE, shall be the only irradiance reference used. Secondary standards or transfer modules shall not be used.

To provide for efficient module testing, module performance may be based on module output at either SOC conditions or at Optional Test Conditions (OTC) defined as $100 \mathrm{~mW} / \mathrm{cm}^{2}$ irradiance, and a cell temperature other than NOCT. When measurements are made at OTC the power output (P) at NOCT cell temperature shall be determined as follows:

$$
P=V_{\mathrm{NO}}\left(\mathrm{I}_{\mathrm{OTC}}+\Delta \mathrm{I}\right)
$$

where

$$
\begin{aligned}
& \mathrm{V}_{\text {NO }}=\text { Module nominal operating voltage at NOCT } \\
& \mathrm{I}_{\mathrm{OTC}}=\text { Modi1.e current measured at OTC and at } \\
& \text { a voltage equal to }\left(\mathrm{V}_{\mathrm{NO}}+\Delta \mathrm{V}\right) \text { volts. } \\
& \Delta \mathrm{I}=\text { Current temperature correction } \\
& =I @\left(\text { NOCT, } V^{\prime}\right)-I @\left(\text { OTC, } V=V^{\prime}+\Delta V\right) \\
& \Delta \mathrm{V}=\text { Voltage temperature correcliun } \\
& =V \Subset\left(O T C, I=I^{\prime}-\Delta I\right)-V @\left(\text { NOCT, } I^{\prime}\right) \\
& \mathrm{V}^{\prime}=\text { Voltage } \approx 0.6 \mathrm{~V}_{\mathrm{OC}} @ \text { NOCT } \\
& I^{\prime}=\text { Current } \approx 0.9 \mathrm{I}_{\mathrm{sc}} \text { @ NOCT } \\
& \mathrm{V}_{\mathrm{nor}}=\text { Open circuit voltage } \\
& I_{S C}=\text { Short circuit current }
\end{aligned}
$$

Determination of the temperature correction factors, $\Delta \mathrm{I}$ and $\Delta \mathrm{V}$, in . the above equation shall be based on actual measurements of a minimum of five prototype modules at both Optional Test Conditions and NOCT $\pm 2^{\circ}$ cell 
temperature. The current-voltage ( $I-V)$ characteristics of each module shall be measured at both conditions. The corresponding I-V curves for the two temperatures may then be overlayed to determine the correction factors. A simultaneous translation of the curves along both current and voltage axes may be made until an accurate match of the curves is accomplished at two points near the maximum power point. The OTC curve should match the NOCT curve at a point where the NOCT current is approximately $90 \%$ of $I_{S G}$ ( $I^{\prime}$ ), and at a second point where the NOCT voltage is approximately $60 \%$ of $V$ ( $\left(V^{\prime}\right)$. The current and voltage shift required to produce the curve match shall be determined for. the exact cell temperature difference between tests. The change per degree $C$ for each factor is then calculated and multiplied by the difference between NOCT and the temperature used for OTC. The resulting $\Delta I$ and $\Delta V$ shall be averaged for the modules tested to establish temperature correction factors to be used when testing modules at other than SOC. Alternate temperatinre correction procedures such as that provided by computer controlled Targe-Area Pulsed solar Simulator (Xenon source) may be used if approved by DOE.

\section{B. NOMINAL OPERATING CELL TEMPERATURE}

\section{Purpose}

The purpose of this test is to acquire sufficient data to allow an accurate determination of the nominal operating temperatures of the solar cells of a terrestrial solar array module.

By definition, the Nominal Operating Cell Temperature (NOCT) is the module cell temperature under operating conditions in the Nominal Thermal Environment (NTE) which is defined as:

$$
\begin{aligned}
& \text { Insolation }=80 \mathrm{~mW} / \mathrm{cm}^{2} \\
& \text { Air Temperature }=20^{\circ} \mathrm{C} \\
& \text { Wind Average Velocity }=1 \mathrm{~m} / \mathrm{s} \\
& \text { Mounting = Tilted, Upen Back, Open Cirsuit }
\end{aligned}
$$

The NOCT test prosedure is bascd on gathering actual measured cell temperature data via thermocouples attached directly to the cells of interest, for a range of environmental conditione oimilar to the NTE. The data are then presented in a way that allows arcurate and rcprntahle intespulation of the NOCT temperature.

\section{Determination of NOCT}

The temperature of the solar cell ( $\mathrm{T}_{\mathrm{cell}}$ ) is primarily a function of the air temperature $\left(\mathrm{T}_{\mathrm{air}}\right)$, the average wind velocity $(\overline{\mathrm{v}})$, and the total solar insolation (L) impinging on the active side of the solar array module. The approach for determining NOCT is based on the fact that the temperature difference $\left(\mathrm{T}_{\mathrm{cell}}-\mathrm{T}_{\mathrm{air}}\right)$ is largely independent of 
air temperature and is essentially linearly proportional to the insolation level. Analyses indicate that the linear assumption is quite good for insolation levels greater than about $40 \mathrm{~mW} / \mathrm{cm}^{2}$. The procedure calls for plotting $\left(\mathrm{T}_{\mathrm{cel1}} \mathrm{T}_{\mathrm{Tir}}\right)$ against the insolation level for a period when wind conditions are favorable. The NOCT value is then determined by adding $\mathrm{T}_{\mathrm{air}}=20^{\circ} \mathrm{C}$ to the value of $\left(\mathrm{T}_{\mathrm{cell}}-\mathrm{T}_{\mathrm{air}}\right)$ interpolated for the NTE insolation level of $80 \mathrm{~mW} / \mathrm{cm}^{2}$, i.e., NOCT $=\left(\mathrm{T}_{\text {cell }}{ }^{-\mathrm{T}}\right.$ air $) \mid \mathrm{NTE}+20^{\circ} \mathrm{C}$.

The plot of $\left(\mathrm{T}_{\mathrm{cell}}-\mathrm{T}_{\mathrm{air}}\right)$ vs $\mathrm{L}$ shall be determined by conducting a minimum of two field tests in which the module being characterized is tested under terrestrial environmental conditions approximating the NTE in accordance with the testing guidelines which follow. Each test shall consist of acquiring a semicontinous record of $\left(\mathrm{T}_{\mathrm{ce} 11}-\mathrm{T}_{\mathrm{air}}\right)$ over a one- or two-day period, together with other measurements as required to characterize the terrestrial environment during the testing period. Acceptable data shall consist of measurements made when the average wind velocity is $1 \mathrm{~m} / \mathrm{s} \pm 0.75 \mathrm{~m} / \mathrm{s}$ and with gusts less than $4 \mathrm{~m} / \mathrm{s}$ for a period of 5 minutes prior to and up to the time of measurement. Local air temperature during the test period shall be $20^{\circ} \mathrm{C} \pm 15^{\circ} \mathrm{C}$. Using only acceptable data as so defined, a plot shall be constructed from a set of measurements made either prior to solar noon or after solar noon which defines the relationship between $\left(\mathrm{T}_{\mathrm{ce}} 11^{-\mathrm{T}_{\mathrm{air}}}\right)$ and the insolation level (L) for $\mathrm{L} \geq 40 \mathrm{~mW} / \mathrm{cm}^{2}$.*

When ( $\mathrm{T}_{\text {cell }}-\mathrm{T}_{\text {air }}$ ) is plotted as a function of $\mathrm{L}$ for average wind velocities less than $1.75 \mathrm{~m} / \mathrm{s}$, results similar to those shown in Figure 4-1 are obtained. For the data shown, the local air temperature was $15.6^{\circ} \mathrm{C}+4.5^{\circ} \mathrm{C}$ and the wind speed varied from zero to less than $4 \mathrm{~m} / \mathrm{s}$ with an average of $1 \mathrm{~m} / \mathrm{s}$. Using the plot of $\left(\mathrm{T}_{\text {cell }}-\mathrm{T}_{\text {air }}\right)$ vs $\mathrm{L}$, the value of $\left(\mathrm{T}_{\mathrm{cell}} \mathrm{T}_{\mathrm{Tir}}\right)$ at $\mathrm{NTE}$ is determined by interpolating the average value of $\left(\mathrm{T}_{\mathrm{cell}}-\mathrm{T}_{\mathrm{air}}\right)$ for $\mathrm{L}=80 \mathrm{~mW} / \mathrm{cm}^{2}$. Using the data in Figure $4-1$ as an example, $\left(\mathrm{T}_{\mathrm{cell}}-\mathrm{T}_{\mathrm{air}}\right)$ at $\mathrm{NTE}$ is determined to be $20.2^{\circ} \mathrm{C}$. The preliminary value of NOCT is thus $20.2^{\circ} \mathrm{C}+20^{\circ} \mathrm{C}=40.2^{\circ} \mathrm{C}$.

\section{Air Temperature and Wind Correction}

A correction factor to the preliminary NOCT for average air temperature and wind velocity is determined from Figure $4-2$. I'h is value is added to the preliminary NOCT and corrects the data to $20^{\circ} \mathrm{C}$ and $1 \mathrm{~m} / \mathrm{s}$. $\mathrm{T}_{\text {air }}$ and $\overline{\mathrm{V}}$ are the average temperature and wind velocity for the test period.

For the test data shown in Figure $4-1, \overline{\mathrm{V}}$ is $1 \mathrm{~m} / \mathrm{s}$ and $\overline{\mathrm{T}}_{\text {air }}$ is $15.6^{\circ} \mathrm{C}$. From Figure $4-2$, the correction factor is $0^{\circ} \mathrm{C}$. The NOCT is therefore $40.2^{\circ} \mathrm{C}$.

*The two sets of measurements can be combined into a single set provided the average air temperature of the two sets does not differ by more than approximately $5^{\circ} \mathrm{C}$. If the average air temperature is significantly different, the resulting effect appears as an increase in the scatter of the plotted data. As a result the data will be more difficull lu fil and a less accuratc recult ie possible. 


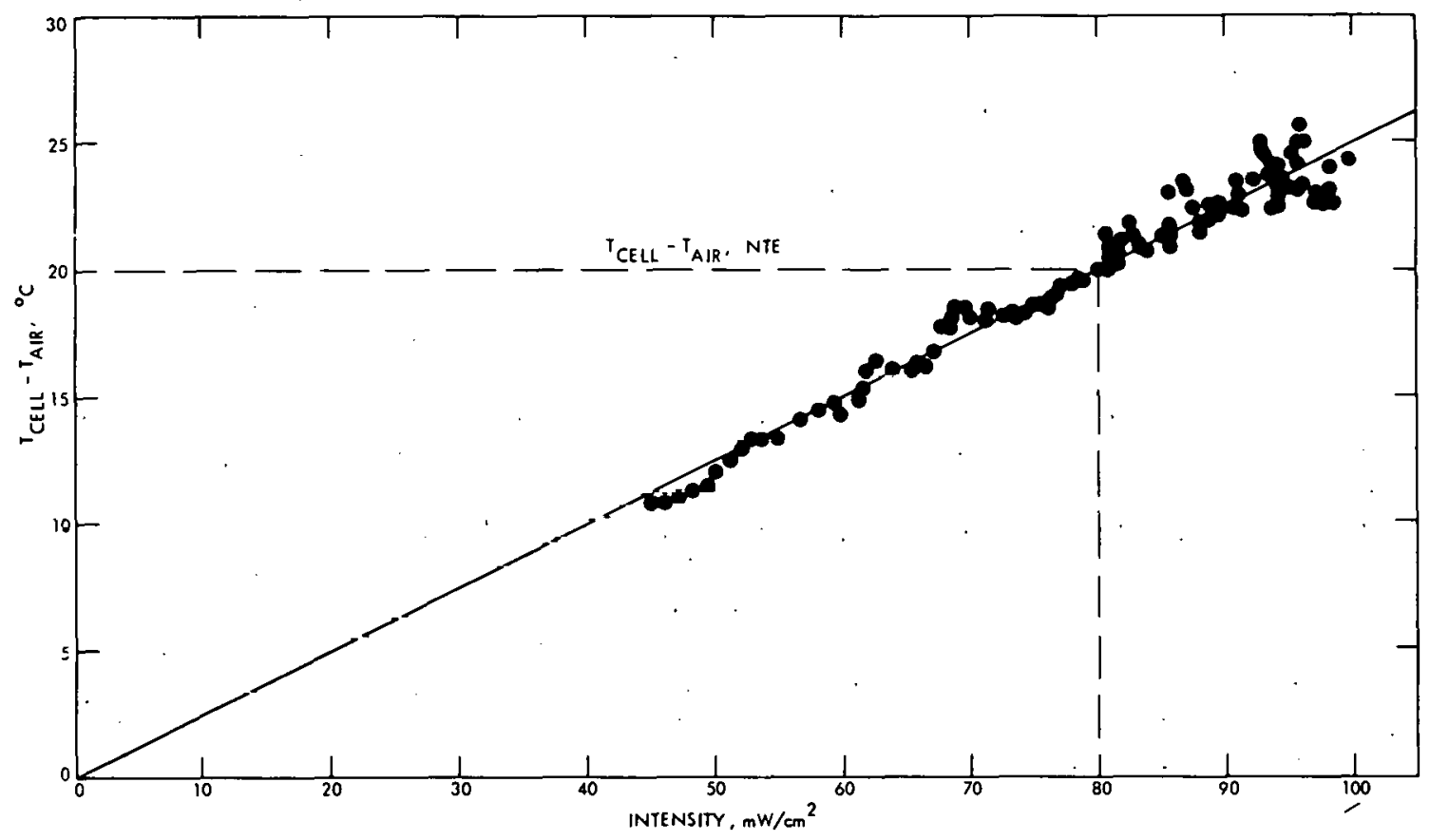

Figure 4-1 Typical Cell Temperature Data

\section{Test Geometry}

a. Tilt Angle. The plane nf the module shall be positioned so that it is normal to the $\operatorname{sun}\left( \pm 5^{\circ}\right)$ at solar noon.

b. Height. The bottom edge of the module shall be 2 feet or more above the local horizontal plane or ground level.

c. Pancl Configuratlon. The module shall be located in the interior of a $1.2 \mathrm{~m} \times 1.2 \mathrm{~m}(4 \mathrm{ft} \times 4 \mathrm{ft})$ panel. Black aluminum panels or other modules of the same design shall be used to fill in any remaining open area of the panel strurturr. The back of the panel shill be exposed.

d. Surrounding Area. There shall be no obstructions to prevent full irradiance of. the module beginning a minimum of 4 hours before solar noon and up to 4 hours after solar noon. The ground surrounding the module shall not have a high solar reflectance and shall be flat and/or sloping away from the test fixture. Grass and various types of ground covers, blacktop, and dirt are recommended for the local 


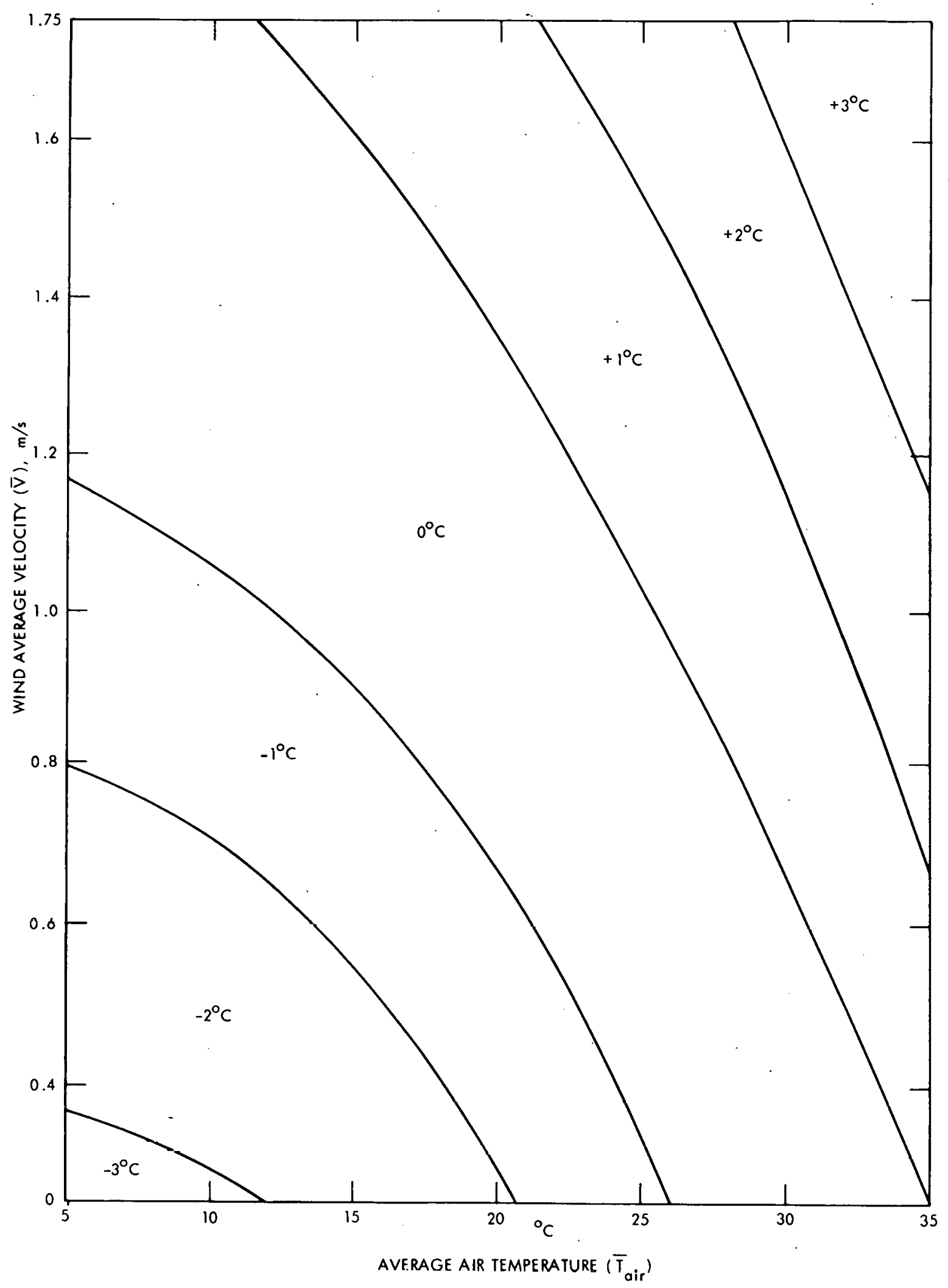

Figure 4-2 NOCT Correction Factor 
surrounding area. Buildings having a large solar reflective finish shall not be present in the immediate vicinity. Good engineering judgment shall be exercised to ensure that the module, both front and back sides, is receiving a minimum of reflected solar energy from the surrounding area.

e. Wind Direction. The wind shall not be predominantly from due east or due west; flow parallel to the plane of the array is not accept$\mathrm{able}$ and can result in a lower-than-typical operating cell temperature.

f. Module Electrical Load. Data shall be obtained for a module open-circuit condition corresponding to zero electrical power output.

5. Test Equipment

a. Pyranometer. The total solar irradiance on the active side of the module shall be measured by a pyranometer mounted on the plane of the module and within $.3 \mathrm{~m}$ ( 1 foot) of the array. The pyranometer used shall have a traceable annual calibration to a recognized standard instrument and shall be either (1) a temperature-compensated unit which has less than $+1 \%$ deviation in sensitivity over the range $-20^{\circ} \mathrm{C}$ to $+40^{\circ} \mathrm{C}$, or (2) $\bar{a}$ unit which incorporates a temperature sensor and has a sensitivity-temperature correction supplied with its calibration.

b. Wind Meacurement. Both the wind directivin and willd speed shall be measured at the approximate height of the module and as near to the module as feasible.

c. Air Temperature. The local air temperature shall be measured at the approximate height of the module. The measurement shall be made in the shadow of the module and shall be accurate to $\pm 1^{\circ} \mathrm{C}$. (Note: An average local air temperature is desired. This is obtained satisfactorily by increasing the thermal mass of the thermocouple by imbedding the thermocouple in a solder sphere or approximately 1/4-inch diameter.) The measurement must be appropriately shielded and vented.

d. Cell Temperature. The temperature of at leașt two representative interior solar cells shall be measured to $t 1^{\mathrm{U}} \mathrm{C}$. Thermocouples shall be 36 gauge, and shall be soft-soldered directly to the back of the cells.

e. Substrate Surface Temperature. The exterior temperature of the rear of the solar module shall be measured to $\pm 1^{\circ} \mathrm{C}$ beneath a representative cell and when practical beneath a representative space between cells. Thermocouples sha11 be 26 gauge, and shall be bonded down with 57-C epoxy or the equivalent. 
6. Data Recording

All data shall be printed out approximately every 2 minutes. In addition, solar intensity, wind speed, wind direction, and air temperature shall be continuously recorded.

\section{Cleaning}

The active side of the solar cell module and the pyranometer bulb shall be cleaned before the start of each test. Dirt shall not be allowed to build up. Cleaning with a mild soap solution followed by a rinse with distilled water has proven to be effective.

\section{Equipment Calibration}

A calibration check shall be made of all the equipment prior to the start of the test. 
SECTION V

TEST PROCEDURES

\section{A. THERMAL CYCLING TEST PROCEDURE}

The module shall be subjected to the thermal cycling procedure per Figure 5-I, consisting of 50 cycles with the cell temperature varying between $-40^{\circ} \mathrm{C}$ and $+90^{\circ} \mathrm{C}$. The temperature shall vary approximately linearly with time at a rate not exceeding $100^{\circ} \mathrm{C}$ per hour and with a period not greater than 6 hours per cycle (from ambient to $-40^{\circ} \mathrm{C}$ to $+90^{\circ} \mathrm{C}$ to ambient). The module circuitry shall be instrumented and monitored throughout the test to verify that no open circuits or short circuits occur during the exposure.

\section{B. HUMIDITY TEST PROCEDURE}

The module shall be subjected to the humidity cycling procedure per Figure 5-2. The module shall be tested in the open circuit condition, but with terminations protected from water condensation. Electrical performance test, per Paragraph IV.A, shall be performed within one hour after removal from the humidity chamber, or within another mutually agreed-upon time period if the testing is subcontracted.

\section{MECHANICAL CYCLING TEST PROCEDURE}

The module shall be subjected to a cyclic load test in which the module is supported only at the design support points and a uniform load normal to the module surface is cycled 10,000 times in an alternating negative and positive direction. Cycle rate shall not exceed 20 cycles/minute. The module circuitry shall be instrumented to verify that no open circuity or short circuits occur during the test. JPL Document 5101-19 "Cyclic Pressure-Load Developmental Testing of Solar Panels," February 1977, describes techniques suitable to the performance of this test.

\section{TWISTED MOUNTING SURFȦCE TEST PROCEDURE}

The module shall be subjected to a twist test by deflection of the suhstrate tn which it is mounted. The deviation from a true flat surface during the test shall be $\pm \frac{1}{4}$ inch per foot measured along either mounting surface as shown in Figure 5-3. The module circuitry shall be instrumented to verify that no open circuits or short circuits occur during the deflection test.

\section{E. HAIL IMPACT, TEST PROCEDURE}

The module shall be subjected to normal impact loading with the required diameter iceball traveling at terminal velocity for the 
specified size. Typical hail characteristics are provided in Table 5-1. At least three different points of impact shall be selected to include the test specimen's most sensitive exposed point, and each point will be struck at least 3 times (a minimum of 9 impacts). The most sensitive exposed point on a test specimen must be determined experimentally through destructive testing of a sample panel. Iceballs $1-1 / 2$ times the required diameter shall be fired at candidate sensitive points with increasing velocity until the panel is broken. Several different points on the panel should be broken, and the points broken at the lowest velocities should be used for subsequent testing.

Table 5-1. Typical Hail Characteristics

\begin{tabular}{|c|c|c|}
\hline $\begin{array}{l}\text { SIZE } \\
\text { in. }\end{array}$ & $\begin{array}{l}\text { WEIGHT* } \\
\text { Ib. }\end{array}$ & $\begin{array}{l}\text { TERMINAL VELOCITY } \\
\mathrm{mph}\end{array}$ \\
\hline $1 / 2$ & 0.0021 & 36 \\
\hline $3 / 4$ & 0.0072 & 45 \\
\hline 1 & 0.017 & 53 \\
\hline $1-1 / 4$ & 0.03 .3 & 58 \\
\hline $1-1 / 2$ & 0.057 & 63 \\
\hline 2 & 0.136 & 73 \\
\hline $2-1 / 2$ & 0.266 & 81 \\
\hline 3 & 0.459 & 89 \\
\hline
\end{tabular}

The candidate points selected should include (where applicable) the following:

(1) Corners and cdges of the module.

(2) Edges of cells, espectally around electrical contracts.

(3) Points of minimum spacing between cells.

(4) Points of support for any superstrate material.

(5) Points of maximum distance from points of support in (4).

Some scatter is expected in hitting a location on a module. Three repeaced Impacts are required to ensure that a sensitive point has been struck. Error of up to $1 / 2$ inch in the location hit is acceptable. Either pneumatic or spring-actuated guns for projecting the iceballs against the modules are acceptable, however iceball velocity at impact must be controlled to within $+5 \%$ of terminal velocity for the required hailstone size. Iceballs shall be generally spherical in shape with a maximum deviation in diameter of $\pm 1 / 8$ inch. The iceballs shall be cooled to $-10^{\circ} \mathrm{C}+2^{\circ}$ as measured in the compartment where they are stored. The module shall be mounted in a manner representative of that used for actual installation of the module in the array. After each impact, the module shall be inspected for evidence of visible damage. Note that 
iceballs are the only acceptable hailstone simulation. Dropped steel balls, for example, shall not be used.

\section{F. ELECTRICAL ISOLATION. TEST PROCEDURE}

The module 'Hi-Pot' test shall be conducted with the output terminations short-circuited. Test leads from" a suitable DC voltage power supply shall be connected with the positive lead on the terminals and the negative lead on the module grounding stud.

In the case of modules not required to provide a grounding stud, the mounting structure shall be used as the second test point. Voltage shall be applied at a rate not to exceed $500 \mathrm{~V} / \mathrm{sec}$ up to the test voltage, and then held at the required test voltage for 1 minute. The module shall be observed during the test for signs of arcing or flashover. Leakage current shall be monitored during the test to verify that leakage current does not exceed 50 microamps. 


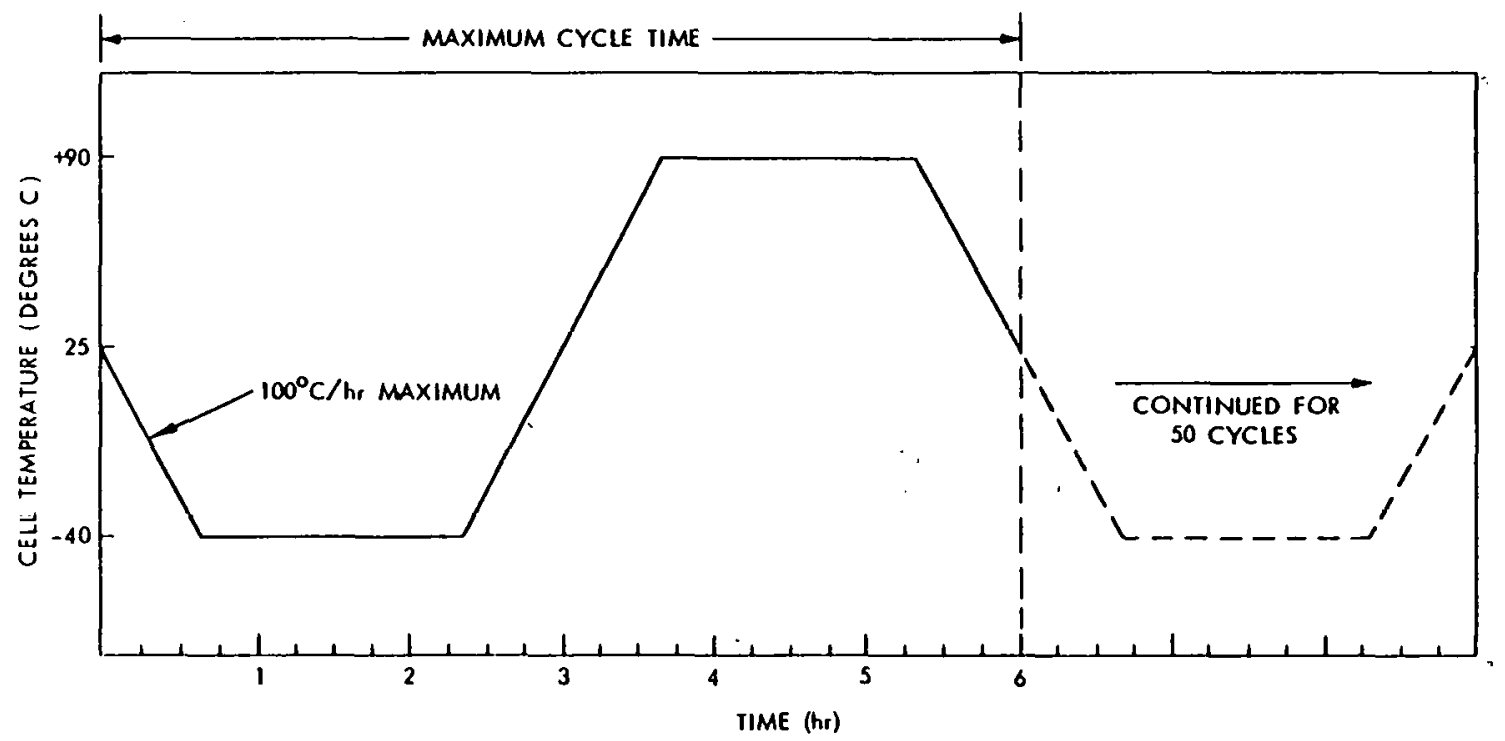

Figure 5-1. Thermal Cycle Test (Shorter cycle time is acceptable if $100^{\circ} \mathrm{C} / \mathrm{hr}$ maximum rate of temperature change is not exceeded. Chamber may be opened at 25 cycles for visual inspection.)

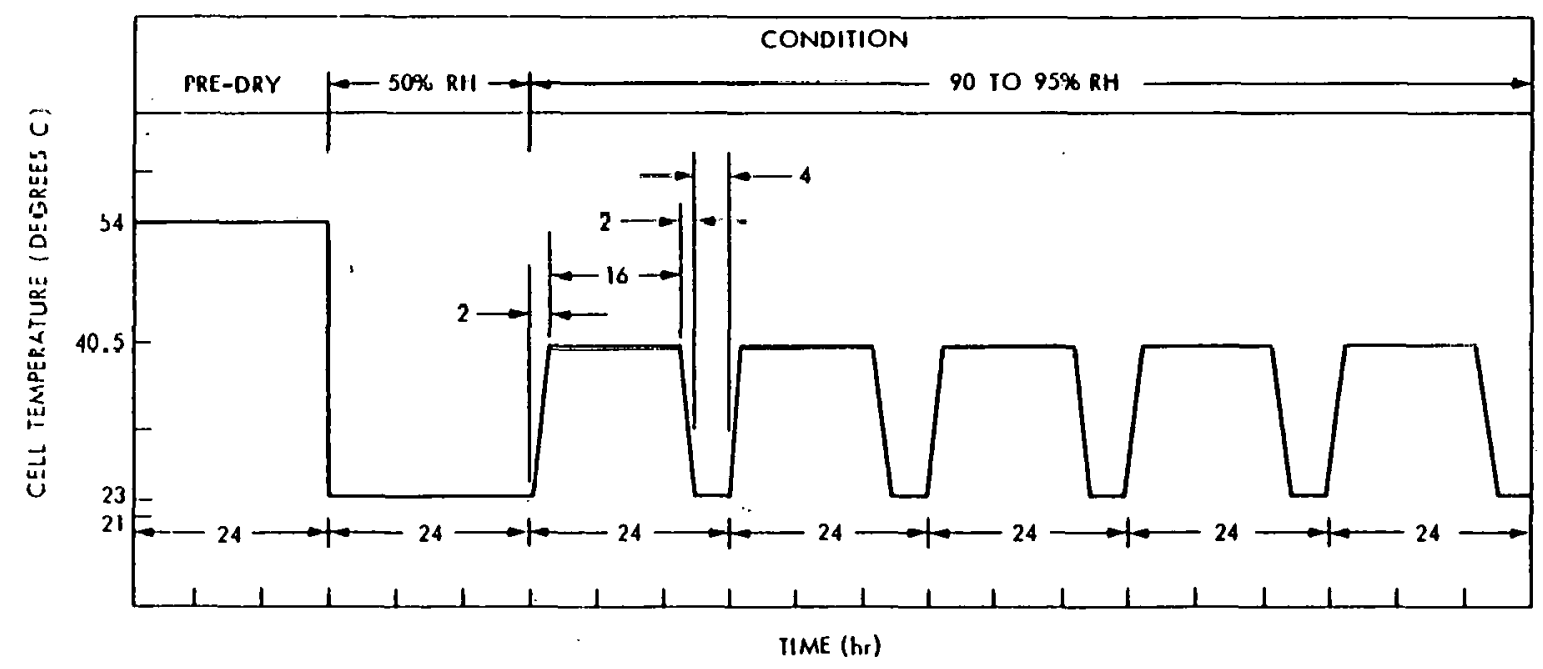

Figure 5-2. Humidity Cycle Test (Suitable procedures for accomplishing this test are described in MIL-STD-810C, Method 507.1, Procedure V.) 


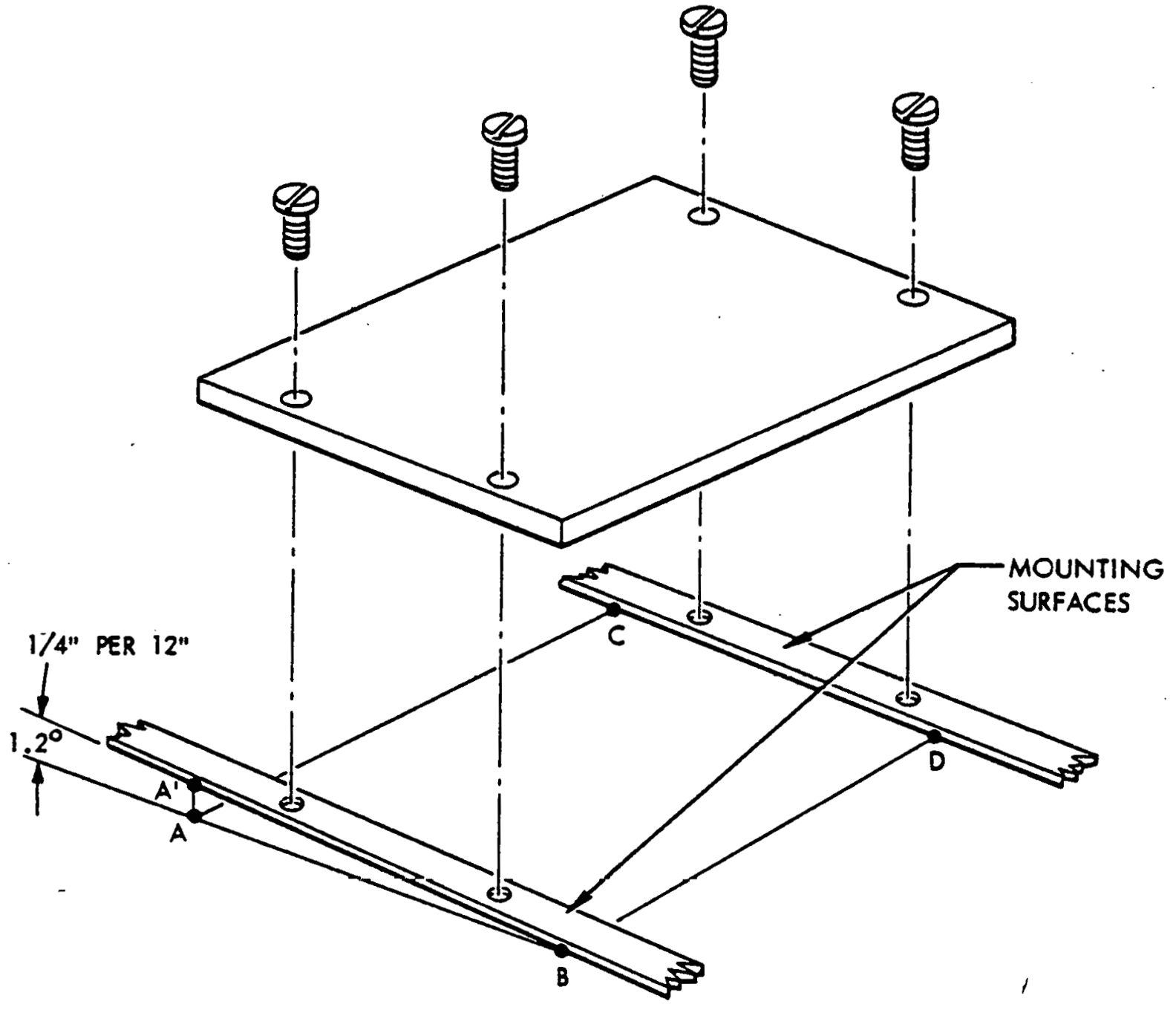

Figure 5-3. Graphical Representation of "Twisted Mounting Surface" Requirement

- Points A, B, C, D are in a Plane

- Point $A^{\prime}$ is out of Plane the Amount Shown 